\title{
Güney Marmara Bölgesindeki Alerjik Rinitli Çocuklarda Mantar Alerjenlerine Duyarlılık Oranlarının Araştırılması
}

\section{A Study on Fungal Allergen Sensitization Rates Among Children with Allergic Rhinitis in the Southern Marmara Region}

\author{
Muhittin Bodur $^{1}$ (D), Yakup Canıtez ${ }^{2}$ (D) Şükrü Çekiç² (D), Gökhan Ocakoğlu ${ }^{3}$, Nihat Sapan² (i)
}

\author{
${ }^{1}$ Bursa Uludağ Üniversitesi, Tıp Fakültesi, Çocuk Sağlığı ve Hastalıkları Anabilim Dalı, Bursa, Türkiye \\ ${ }^{2}$ Bursa Uludağ Üniversitesi, Tıp Fakültesi, Çocuk Sağlığı ve Hastalıkları Anabilim Dalı, Çocuk Alerji Bilim Dalı, Bursa, Türkiye \\ ${ }^{3}$ Bursa Uludağ Üniversitesi, Tıp Fakültesi, Biyoistatistik Anabilim Dalı, Bursa, Türkiye
}

ORCID ID: M.B. 0000-0002-2588-8195; Y.C. 0000-0001-8929-679X; Ş.Ç. 0000-0002-9574-1842; G.0. 0000-0002-1114-6051; N.S. 0000-0002-7601-8392

Atıf/Citation: Bodur M, Canites Y, Cekic S, Ocakoglu G, Sapan N. Güney Marmara Bölgesindeki alerjik rinitli çocuklarda mantar alerjenlerine duyarlılı oranlarının araştırılması. Çocuk Dergisi - Journal of Child 2021;21(2):111-118. https://doi.org/10.26650/jchild.2021.2.853810

Öz

Amaç: Alerjik rinit tanılı çocuklarda, mantar alerjen duyarlılıkları görülme sıklığını ve mantar alerjen duyarlılıkları ile ilişkili faktörlerin araştırılması amaçlanmıştır.

Gereç ve Yöntem: Alerjik rinit tanılı ve deri prik testlerinde en az bir inhalan alerjene karşı duyarlılık saptanmış olan, 2-18 yaşlarında 331 çocuk olgu prospektif olarak çalışmaya alındı. Hastalara standart alerjen solusyonları ile deri prik testi yapıldı.

Bulgular: Alerjik rinitli olguların \%62,5’i erkek ve \%37,5'i kız, semptomların başlangıç zamanı $6,77 \pm 4,06$ yaş olarak saptandı. Alerjik rinitli çocuklarda en sık akar duyarlılığı $(\% 68,8)$, ikinci sırada ise çimen polen duyarlılığı $(\% 48,9)$ tespit edildi. En az bir mantar alerjenine karşı duyarlılık \%10,6 $(n=35)$ oranında saptandı, bu grup içinde en sık Alternaria alternata $(\% 88,5)$ duyarlıı̆̆ı saptandı. Mantar alerjeni duyarlılığı olan grupta mantar alerjeni duyarlılığı saptanmayan gruba göre alerjik rinit semptomlarının başlama yaşı anlamlı olarak daha erken saptandı (sırasıyla 5,23 $\pm 3,44$

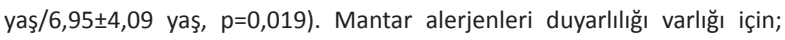
Corylus avellena duyarlılığının veya köpek alerjen duyarlılığının anlamlı risk faktörleri olduğu saptandı. Alerjik rinitli hastalarda ek olarak astım görülmesi açısından; Dermatofagoides farinae duyarlılığı veya hamam böceği duyarlılığı varlığının anlamlı risk faktörleri olduğu tespit edildi.

Sonuç: Alerjik rinitli çocuklarda mantar alerjenlerine karşı duyarlılık, dikkate değer bir oranda görülmektedir. Mantar alerjenlerine duyarlılığın büyük kısmını Alternaria alternata duyarlılığı oluşturmaktadır.

Anahtar Kelimeler: Alerjik rinit, alerjen, çocuk, duyarlılık, mantar, mantar duyarlılığı

\section{ABSTRACT}

Objective: The aim of this study was to investigate the frequency of fungal allergen sensitivities and the factors associated with fungal allergen sensitivities in children with allergic rhinitis.

Method: 331 children aged 2-18 years who were diagnosed with allergic rhinitis and had sensitivity to at least one inhalant allergen in skin prick tests were prospectively included in the study. The skin prick test was performed with standard allergen solutions.

Results: $62.5 \%$ of the patients with allergic rhinitis were boys and $37.5 \%$ were girls, and the onset of symptoms was $6.77 \pm 4.06$ years old. Mite sensitivity (68.8\%) was the most common in children with allergic rhinitis, followed by grass pollen sensitivity (48.9\%). Sensitivity to at least one fungal allergen was detected at a rate of $10.6 \%(n=35)$, the most common among this group being Alternaria alternata (88.5\%). The age of onset of allergic rhinitis symptoms was found to be significantly earlier in the group with fungal allergen sensitivity compared to the group without fungal allergen sensitivity $(5.23 \pm 3.44$ years/6.95 \pm 4.09 years, respectively, $\mathrm{p}=0.019$ ). For the presence of sensitivity to fungal allergens; Corylus avellena sensitivity or dog allergen sensitivity were found to be significant risk factors. In terms of additional asthma in patients with allergic rhinitis; Dermatophagoides farinae sensitivity or presence of cockroach sensitivity were found to be significant risk factors.

Conclusion: Sensitivity to fungal allergens is observed at a remarkable rate in children with allergic rhinitis. Most of the sensitivity to fungal allergens is Alternaria alternata sensitivity.

Keywords: Allergic rhinitis, child, fungus, fungal sensitivity, allergen, sensitivity

Sorumlu Yazar/Corresponding Author: Muhittin Bodur E-mail: dr_muhittin@hotmail.com

Başvuru/Submitted: 05.01.2021 • Revizyon Talebi/Revision Requested: 08.07.2021 • Son Revizyon/Last Revision Received: $26.07 .2021 \bullet$ Kabul/Accepted: 27.07 .2021 


\section{GíRiş}

Rinit tanımı, burun tıkanıklığı, burun akıntısı, hapşırma ve kaşınt gibi semptomlardan bir veya daha fazlasının varlığı ile tanımlanmaktadır (1). Rinit, alerjik veya alerjik olmayan rinit türleri olarak patojenik mekanizmalara göre sınıflandırılır. Rinit terim olarak inflamasyonu ifade etse de alerjik rinit ve alerjik olmayan rinitin bazı türleri (alerjik olmayan rinit eozinofili sendromu-NARES gibi) nazal mukoza inflamasyonu ile ilişkili iken, vazomotor rinit gibi bazı alerjik olmayan rinit formları ise nazal mukoza inflamasyonu ile ilişkili değildir (2). Alerjik rinit; burun mukozasının alerjenlere maruziyeti ile IgE aracılı inflamasyonu sonucu gelişen, çocukluk çağında sık görülen bir alerjik hastalıktır (3).

Mantar sporlarının çapları 3-10 $\mu \mathrm{m}$ arasında olup alt solunum yollarına kadar ulaşabilirler. Dünyada 1 milyon'dan fazla mantar türü vardır, ancak bunlardan sadece 100 kadarı solunum sisteminde alerjik semptomlara neden olur (4). Mantar alerjenleri başlıca iç ortam ve dış ortam mantarları olarak iki grupta incelenir. En önemli dış ortam mantarları, Alternaria ve Cladosporium, iç ortam mantarları ise Penicillium ve Aspergillus'dur (5). Mantarlar özellikle sıcak ve nemli iç ortamlarda tüm yıl boyunca üreme yeteneğine sahiptirler. Ev içinde yıl boyu bulunabilirlerse de miktarları yaz ve sonbahar aylarında daha fazladır. İç ortam mantar düzeyi hem iç hem de dış ortam mantar düzeyinin karışımı şeklinde ortaya çıkabilmektedir (6).

Alerjik duyarlılanmaya neden olan solunum alerjenleri bölgelere göre farklılık göstermektedir (7). Ülkemizde çocukluk çağında alerjik rinitli olgularda mantar alerjenlerine karşı duyarlılığı araştıran çalışmalar az sayıdadır. Literatürde, Bursa ve Güney Marmara bölgesindeki alerjik rinitli çocuklarda, mantar alerjenlerine duyarııı̆ının araştırıldığı çalışmalar bulunmamaktadır. Bu çalışmanın amacı Güney Marmara bölgesinde alerjik rinit tanısı alan çocuk hasta grubunda mantar ve diğer inhalan alerjenlere karşı duyarlılık oranlarının saptanması, mantar alerjenlerine karşı duyarlılık saptanan olguların özellikleri ve diğer inhalan alerjen duyarlılıkları ile ilişkileri, mantar alerjen duyarlılığına etki eden diğer ilişkili faktörlerin araştrıımasıdır.

\section{GEREÇ VE YÖNTEM}

Uludağ Üniversitesi Tıp Fakültesi Çocuk Alerji Polikliniğine 01.07.2010-30.06.2011 tarihleri arasında ardısıra başvurarak alerjik rinit tanısı alan ve deri prik testinde en az bir inhalan alerjene karşı duyarlııı saptanan, yaşları 2-18 yıl arasında 331 olgu prospektif olarak çalışmaya alındı. Olguların yakınmalarının başlangıç yaşı, alerjik rinit tanı yaşı, ek alerjik hastalık varlığı sorgulandı. Tüm olgulara uygulanan deri prik testleri sonuçları, kan total eozinofil ve serum total IgE düzeyleri kaydedildi.

Deri prik testleri, ALK-Abello (Horsholm, Denmark) standart inhalan alerjen solüsyonları ve tek kullanımlık plastik lansetler (Stallergenes, Antony, France) kullanılarak Uludağ Üniversitesi Tıp Fakültesi Çocuk Alerji Bilim Dalı Laboratuvarında uygulandı. Alerjenler, her iki ön kolun volar yüzüne en az $2 \mathrm{~cm}$ aralıklarla damlatıldıktan sonra her alerjen için farklı lanset kullanı- larak alerjenlerin yaklaşık $1 \mathrm{~mm}$ derinliğe ulaşması sağlandı. Pozitif kontrol için histamin \%0,1 (1 mg/ml), negatif kontrol için serum fizyolojik solüsyonu kullanıldı. Deri testlerinde alerjenler uygulandıktan $15 \mathrm{dk}$ sonra negatif kontrole kıyasla 3 $\mathrm{mm}$ veya daha fazla ödem saptandığında pozitif kabul edildi (8). Deri prik testlerinde, her olguya hastanın yaş ve klinik özelliklerine göre farklı inhalan alerjenler uygulanmıştır. Yaygın inhalan alerjenlerle deri prik testlerinde uygulanan alerjenler (her bir alerjen için çalışan hasta sayısı parentez içinde verilmiştir); Alternaria alternata (331 olgu), Cladosporium herbarum (331 olgu), Aspergillus fumigatus (331 olgu), Penicillium notatum (331 olgu), Mucor mucedo (331 olgu), Candida albicans (331 olgu), Dermatophagoides pteronyssinus (331 olgu), Dermatophagoides farinae (331 olgu), Cynodon dactylon (278 olgu), Lolium perenne (189 olgu), Phleum pratense (292 olgu), Secale cereale (297 olgu), Avena sativa (277 olgu), Olea europeae (324 olgu), Corylus avellena (269 olgu), Alnus glutinosa (297 olgu), Artemisia vulgaris (232 olgu), Plantago lanceolata (109 olgu), Parieteria judaica (142 olgu), kedi (Felis domesticus) (296 olgu), köpek (Canis familiaris) (299 olgu), hamam böceği (Blatella germanica) (324 olgu). Ek olarak deri prik test sonuçları incelenirken her bir alerjen grubu için o gruba ait genel duyarlılık sonuçları da (o gruptan en az bir alerjene karşı duyarlılık varlığında; akar genel duyarlılığı, çimen polenleri genel duyarlıı̆̆ı vb. gibi) belirlendi.

Serum total IgE ölçümlerinde Immulite 2000 (DPC-Diagnostik Products Corporation, Los Angeles CA, USA) test kitleri kullanıldı ve sonuçlar IU/ml olarak verildi. Total eozinofil düzeyleri Sysmex XT-1800i cihazı ile impedans yöntemi ile ölçüldü ve sayı $/ \mathrm{mm}^{3}$ olarak değerlendirildi.

İstatistiksel hesaplamalar SPSS 13.01 programı kullanılarak yapıldı. Verileri karşılaştırmak için ki-kare testi, Fisher'in kesin ki-kare testi, t-testi kullanıldı. Lojistik regresyon analizi ile değişkenlerin birbirleriyle etkileşimleri incelendi. İstatistiksel anlamlılık seviyesi için $p<0,05$ eşik değer olarak kabul edildi. Sayısal ölçüm verileri aritmetik ortalama $(A O)$ ve \pm standart hata $( \pm \mathrm{SH})$ olarak belirtildi. Araştrrma için Uludağ Üniversitesi Tıp Fakültesi Bilimsel Araştırmalar Etik Kurulundan (2009.11/72 tarih ve sayılı kararı) onay alındı.

\section{BULGULAR}

Çalışmada yer alan tüm alerjik rinitli çocuk olguların $(n=331)$ genel özellikleri Tablo 1'de verilmiştir. Olguların \%62,5'i erkek ( $n=207), \% 37,5^{\prime} i$ kız ( $\left.n=124\right)$, ortalama tanı yaşı 9,30 $\pm 3,97$ yıl (medyan:8,91, minimum:2,33, maksimum:17,75 yıl) ve semptomların başlangıç zamanı 6,77£4,06 yıl (medyan:6,41, $\min .: 2,05$, maks.:17,0 yıl) olarak saptandı. Alerjik rinitli olgularda klinik semptomlar, $154(\% 46,5)$ olguda perennial ve 177 $(\% 53,5)$ olguda mevsimsel özellik göstermekteydi. Alerjik rinite eşlik eden diğer alerjik hastalıklar sorgulandığında; 130 olguda $(\% 39,3)$ astım, 115 olguda $(\% 34,7)$ alerjik konjuktivit, 12 olguda $(\% 3,6)$ atopik dermatit saptandı.

Çalışma grubundaki tüm olgularda ( $n=331$ ) çeşitli alerjen gruplarına ve alerjenlere karşı saptanan duyarlılık oranlarının dağılımı Şekil 1'de gösterilmiştir. Deri prik testlerinde en sık saptanan 
Tablo 1: Çalışmada yer alan alerjik rinitli çocuk hastaların genel özellikleri $(n=331)$

\begin{tabular}{|c|c|c|}
\hline & Hasta sayısı (n=331) & \\
\hline & $\mathrm{n}$ & (\%) \\
\hline \multicolumn{3}{|l|}{ Cinsiyet } \\
\hline Erkek & 207 & 62,5 \\
\hline $\mathrm{K} \mathrm{IZ}$ & 124 & 37,5 \\
\hline \multicolumn{3}{|l|}{$\begin{array}{l}\text { Semptomların başlangıç } \\
\text { zamanı(yıl) }\end{array}$} \\
\hline Mean $\pm S D$ & \multicolumn{2}{|l|}{$6,77 \pm 4,06$} \\
\hline Min-max & \multicolumn{2}{|l|}{$2,05-17,0$} \\
\hline Median & \multicolumn{2}{|l|}{6,41} \\
\hline \multicolumn{3}{|l|}{ Tanı yaşı (yıl) } \\
\hline Mean $\pm S D$ & \multicolumn{2}{|l|}{$9,30 \pm 3,97$} \\
\hline Min-max & \multicolumn{2}{|l|}{$2,33-17,75$} \\
\hline Median & \multicolumn{2}{|l|}{8,91} \\
\hline \multicolumn{3}{|c|}{$\begin{array}{l}\text { Hastalarda alerjik rinite eşlik } \\
\text { eden ek alerjik hastalıklar }\end{array}$} \\
\hline Astım & 130 & 39,3 \\
\hline Alerjik konjunktivit & 115 & 34,7 \\
\hline Atopik dermatit & 12 & 3,6 \\
\hline Ürtiker & 11 & 3,3 \\
\hline Besin alerjisi & 2 & 0,6 \\
\hline İlaç alerjisi & 2 & 0,6 \\
\hline Alerjik rinit semptomları & 154 & 46,5 \\
\hline Perennial alerjik rinit & 177 & 53,5 \\
\hline Mevsimsel alerjik rinit & & \\
\hline
\end{tabular}

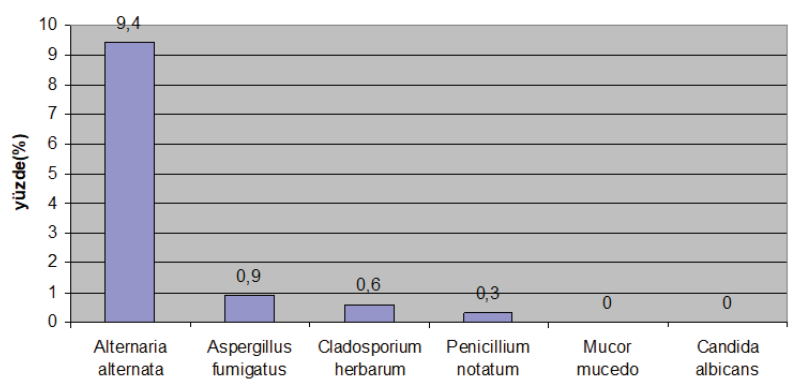

Şekil 1: Alerjik rinitli tüm olgularda $(n=331)$ deri prik testleri ile saptanan çeşitli inhalan alerjen grupları ve alerjenlere göre duyarlılıkların dağılımı

*genel: o gruptaki alerjenlerden en az birine karşı pozitif deri prik testi sonucu varlığı

duyarlılık, akarlara karşı saptanmışt $(\% 68,8)$. Çimen polen genel duyarlıığı ise $\% 48,9$ oranında ve ikinci sıklık sırasında belirlenmişti. En az bir mantar sporuna karşı duyarlılık (mantar genel duyarlılığı) ise olguların \%10,6'sında ( $n=35)$ saptandı.

Alerjik rinitli tüm olgularda ( $n=331$ ) çeşitli mantar alerjenlerine karşı saptanan duyarlılık oranları Şekil 2'de gösterilmiştir. Alerjik rinitli tüm olgularda ( $n=331)$ mantar alerjenlerine karşı duyarlıIıklar; Alternaria alternata ( $n=31, \% 9,4)$, Aspergillus fumigatus $(n=3, \% 0,9)$, Cladosporium herbarum $(n=2, \% 0,6)$, Penicillium notatum ( $n=1, \% 0,3$ ) oranlarında saptandı. Mucor mucedo ve Candida albicans duyarlılığı hiçbir olguda saptanmadı.

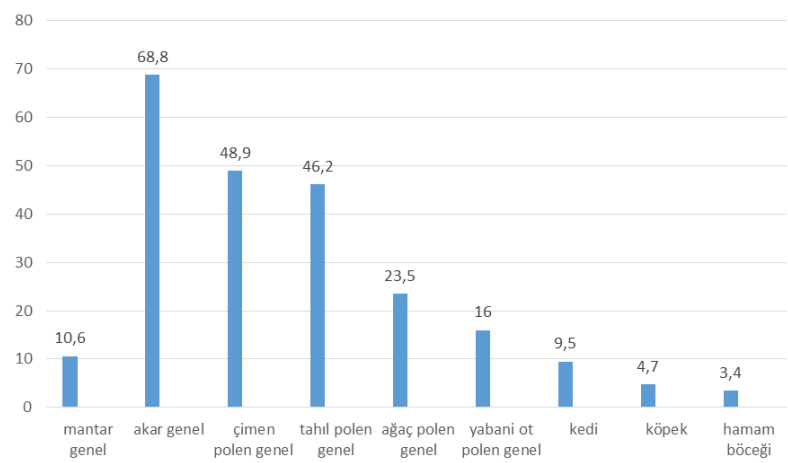

Şekil 2: Alerjik rinitli tüm olgularda $(n=331)$ deri prik testleri ile çeşitli mantar alerjenlerine karşı saptanan duyarlılık oranları

En az bir mantar alerjenine karşı duyarlılık (mantar genel duyarlılığı) saptanan 35 olgu $(\% 10,6)$ içinde, Alternaria alternata duyarlılığı \%88,5 oranı ile ilk sırada tespit edildi. Mantar alerjeni duyarlıığı bulunan toplam 35 alerjik rinitli olgunun; 7 'sinde (\%20) monosensitizasyon (sadece bir mantar alerjenine duyarlılık varlığı) saptandı, bu monosensitize 7 olgunun tümünde (\%100) sadece Alternaria alternata duyarlılığı mevcuttu. Polisensitizasyon (mantar sporu duyarlılığına diğer mantar sporu duyarlılıkları veya diğer inhalan alerjen duyarlılıklarının eşlik etmesi) ise 28 olguda (\%80) saptandı. Özetle, 331 alerjik rinitli olgunun 7'sinde $(\% 2,1)$ monosensitize Alternaria alternata duyarlılığı mevcut iken, $28^{\prime}$ inde $(\% 8,5)$ polisensitize mantar duyarlılığı mevcuttu.

Deri prik testlerinde mantar alerjeni duyarlılığı saptanan ve saptanmayan alerjik rinitli olguların çeşitli özellikleri karşılaştırıldığında (Tablo 2); semptomların başlangıç yaşı mantar alerjeni duyarlıı̆ı̆ olan grupta [ortalama başlangıç yaşı 5,23 $\pm 3,44$ yıl (medyan:5,0, min.:2,05, maks.:14 yıl)], olmayanlara göre [or-

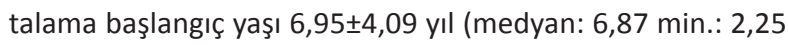
maks.: 17yıl)] anlamlı olarak daha düşük saptandı $(p=0,019)$. Cinsiyet ve ilk kez doktor tarafindan alerjik rinit tanısı aldığı yaş açısından iki grup arasında anlamlı farklılıklar saptanmadı.

Mantar alerjeni duyarlılığı saptanan ve saptanmayan alerjik rinitli olguların diğer alerjenlere duyarlılık oranları Tablo 3'de verilmiştir. Mantar alerjenleri duyarlılığı olanlarda akar genel, Dermatophagoides pteronyssinus ve Dermatophagoides farinae duyarlılıkları anlamlı olarak daha düşük (sırasıyla, $\mathrm{p}=0,028$, $\mathrm{p}=0,017, \mathrm{p}=0,014)$, Alnus glutinosa, Corylus avellena, yabani ot genel, Artemisia vulgaris, köpek alerjen duyarlılıkları anlamlı olarak yüksek bulunmuştur (sırasıyla, $p=0,012, p=0,003$, $p<0,001, p=0,022, p=0,002$ ).

Alerjik rinitli tüm olgularda; ortalama total eozinofil sayısı: $458,97 / \mathrm{mm}^{3} \pm 389,76$ (medyan:351,5 min.:7 maks.:2380), ortalama total IgE düzeyi: 334,05 IU/ml $\pm 485,19$ (medyan:173 min.:1,66 maks.:3194) olarak saptandı. Mantar alerjeni duyarIılığı saptanan grupta ortalama total eozinofil sayısı: 448,71/ $\mathrm{mm}^{3} \pm 391,24$ (median: $328 \mathrm{~min} .: 26$ maks.:1440), ortalama total IgE düzeyi: 253,65 IU/ml $\pm 229,8$ (median:194,5 min.:13,16 maks.:1000) ve saptanmayan grupta ise ortalama total eozinofil sayısı: 460,16/mm³ $\pm 390,38$ (median:356,5 min.:7 maks.:2380), 
Tablo 2: Mantar alerjenlerine duyarlılık saptanan ve saptanmayan olguların çeşitli özelliklerinin karşılaştırılması

\begin{tabular}{|c|c|c|c|c|c|}
\hline & \multicolumn{2}{|c|}{$\begin{array}{l}\text { Mantar genel* duyarlılı̆ı̆ saptanan } \\
\text { olgular }(n=35)\end{array}$} & \multicolumn{2}{|c|}{$\begin{array}{l}\text { Mantar genel* duyarlılı̆̆ı saptanmayan } \\
\text { olgular }(n=296)\end{array}$} & \multirow{2}{*}{$\mathbf{p}$} \\
\hline & n & $\%$ & $\mathbf{n}$ & $\%$ & \\
\hline \multicolumn{6}{|l|}{ Cinsiyet } \\
\hline Erkek & 22 & 62,9 & 185 & 62,5 & 1,00 \\
\hline $\mathrm{K} ı \mathrm{z}$ & 13 & 37,1 & 111 & 37,5 & \\
\hline \multicolumn{6}{|c|}{ Semptomların başlangıç zamanı(yıl) } \\
\hline Mean & $5,23 \pm 3,44$ & & $6,95 \pm 4,09$ & & 0,019 \\
\hline Min-max & $2,05-14$ & & $2,25-17,0$ & & \\
\hline Median & 5 & & 6,87 & & \\
\hline \multicolumn{6}{|l|}{ Tanı yaşı(yıl) } \\
\hline Mean & $8,87 \pm 3,33$ & & $9,36 \pm 4,04$ & & 0,56 \\
\hline Min-max & $3,25-15,5$ & & $2,33-17,75$ & & \\
\hline Median & 8,58 & & 9,0 & & \\
\hline Perennial alerjik rinit & 13 & 37,1 & 141 & 47,6 & \\
\hline Mevsimsel alerjik rinit & 22 & 62,8 & 155 & 52,3 & 0,318 \\
\hline
\end{tabular}

*genel duyarlıık: mantar alerjenlerinden en az birine karşı pozitif deri prik testi sonucu varlığı

Tablo 3: Mantar alerjenleri duyarlılığı saptanan ve saptanmayan olguların diğer alerjenlere duyarlılık oranlarının karşılaştırılması.

\begin{tabular}{|c|c|c|c|c|c|}
\hline & \multicolumn{2}{|c|}{$\begin{array}{l}\text { Mantar genel* duyarlılığı saptanan } \\
\text { olgular }(n=35)\end{array}$} & \multicolumn{2}{|c|}{$\begin{array}{c}\text { Mantar genel* duyarlılığı saptanmayan } \\
\text { olgular }(n=296)\end{array}$} & \multirow{2}{*}{$\mathbf{p}$} \\
\hline & $\mathbf{n}$ & $\%$ & $\mathbf{n}$ & $\%$ & \\
\hline Akar genel* duyarlılığı & $18(n=35)$ & 51,4 & $210(n=296)$ & 70,9 & 0,028 \\
\hline Dermatophagoides farinae & $15(n=35)$ & 42,8 & $199(n=296)$ & 67,2 & 0,014 \\
\hline Dermatophagoides pteronyssinus & $17(n=35)$ & 48,6 & $207(n=296)$ & 69,9 & 0,017 \\
\hline Çimen polen genel* duyarlılığı & $21(n=35)$ & 60,0 & $141(n=296)$ & 47,6 & 0,235 \\
\hline Cynodon dactylon & $16(n=30)$ & 53,3 & $103(n=248)$ & 41,5 & 0,299 \\
\hline Lolium perenne & $7(n=16)$ & 43,8 & $79(n=173)$ & 45,7 & 1,00 \\
\hline Phleum pratense & $20(n=33)$ & 60,6 & $119(n=259)$ & 45,9 & 0,161 \\
\hline Tahıl polen genel* duyarlılığı & $20(n=35)$ & 57,1 & $133(n=296)$ & 44,9 & 0,232 \\
\hline Avena sativa & $15(n=31)$ & 48,4 & $108(n=246)$ & 43,9 & 0,778 \\
\hline Secale cereale & $19(n=33)$ & 57,6 & $122(n=264)$ & 46,2 & 0,295 \\
\hline Ağaç polen genel* duyarlılığı & $15(n=35)$ & 42,9 & $63(n=296)$ & 21,2 & 0,08 \\
\hline Alnus glutinosa & $7(n=33)$ & 21,2 & $18(n=264)$ & 6,8 & 0,012 \\
\hline Corylus avellena & $7(n=32)$ & 21,9 & $12(n=237)$ & 5,1 & 0,003 \\
\hline Olea europeae & $9(n=35)$ & 25,7 & $46(n=289)$ & 15,9 & 0,223 \\
\hline Yabani ot polen genel* duyarlılığı & $14(n=35)$ & 40,0 & $39(n=296)$ & 13,1 & $<0,001$ \\
\hline Artemisia vulgaris & $6(n=27)$ & 22,2 & $15(n=205)$ & 7,3 & 0,022 \\
\hline Plantago lanceolata & $1(n=11)$ & 9,1 & $4(n=98)$ & 4,1 & 0,419 \\
\hline Pariteria judaica & $3(n=19)$ & 15,8 & $11(n=123)$ & 8,9 & 0,402 \\
\hline \multicolumn{6}{|l|}{ Diğer } \\
\hline Kedi & $6(n=34)$ & 17,6 & $22(n=262)$ & 8,4 & 0,112 \\
\hline Köpek & $6(n=33)$ & 18,2 & $8(n=266)$ & 3 & 0,002 \\
\hline Hamam böceği & $2(n=35)$ & 5,7 & $9(n=289)$ & 3,1 & 0,337 \\
\hline
\end{tabular}

*genel duyarlılık: o gruptaki alerjenlerden en az birine karşı pozitif deri prik testi sonucu varlığı 
ortalama total IgE düzeyi: $344,8 \mathrm{IU} / \mathrm{ml} 8 \pm 509,34$ (median:168 $\min .: 1,66$ maks.:3194) olarak saptandı. Mantar alerjeni duyarlılığı saptanan ve saptanmayan gruplar arasında total IgE düzeyleri ve total eozinofil sayıları açısından istatistiksel anlamlı farklılıklar saptanmadı (her iki değişken için $p>0,05$ ).

Alerjik rinit (sadece alerjik rinit) ve alerjik rinitle birlikte astımı var olan olguların karşılaştırılması Tablo 4'de verilmiştir. Alerjik rinitli olgularda sadece alerjik rinitli olgular ile alerjik rinitle birlikte astımı var olan olgular karşılaştırıldığında; alerjik rinitle birlikte astımı var olan olgularda akar genel, Dermatophagoides pteronyssinus, Dermatophagoides farinae, hamam böceği duyarlılıkları anlamlı olarak yüksek $(p=0,002, p=0,003, p=0,001$, $p=0,027)$ bulunurken; alerjik rinitle birlikte astımı var olan olgularda çimen polenleri genel, Cynodon dactylon, Phleum pratense, tahıl polen genel, Secale cereale duyarlılıkları ise anlamlı olarak daha düşük $(p=0.047, p=0,041, p=0,018, p=0,012$, $p=0,016)$ oranlarda bulundu.

Mantar alerjenleri duyarlılığı varlığı için, diğer inhalan alerjen duyarlııkları varlıklarının olası risk faktörü olup olmadığı incelendi, lojistik regresyon analizi sonucu elde edilen model anlamlı bulunmuştur $(p<0,001)$. Mantar alerjenleri duyarlılığını, Corylus avellena duyarlılığının 5,32 kat (OR: 5,32; $95 \% \mathrm{Cl}: .1,5-$ $18,3 ; p=0,008)$, köpek alerjen duyarlılığı varlığının ise 6,58 kat (OR: 6,58; 95\%Cl:.1,6-27; $\mathrm{p}=0,009$ ) artırdığı saptandı. Alerjik

Tablo 4: Sadece alerjik rinitli olgular ile alerjik rinite astımın eşlik ettiği olguların alerjen duyarlılık oranlarının karşılaştırılması (test uygulanan hasta sayısı parantez içinde verilmiştir)

\begin{tabular}{|c|c|c|c|c|c|}
\hline & \multicolumn{2}{|c|}{$\begin{array}{l}\text { Sadece alerjik rinitli olgular } \\
\qquad(n=201)\end{array}$} & \multicolumn{2}{|c|}{$\begin{array}{l}\text { Alerjik rinit ve astımlı olgular } \\
\qquad(n=130)\end{array}$} & \multirow{2}{*}{$\mathbf{p}$} \\
\hline & $\mathbf{n}$ & $\%$ & $\mathbf{n}$ & $\%$ & \\
\hline Mantar genel* duyarlılığı (en az bir mantara karşı duyarlııı) & $19(n=201)$ & 9,5 & $16(n=130)$ & 12,3 & 0,521 \\
\hline Alternaria alternata & $17(n=201)$ & 8,5 & $14(n=130)$ & 10,8 & 0,609 \\
\hline Aspergillus fumigatus & $1(n=201)$ & 0,5 & $2(n=130)$ & 1,5 & 0,563 \\
\hline Cladosporium herbarium & $0(n=201)$ & 0 & $2(n=130)$ & 1,5 & 0,154 \\
\hline Penicillium notatum & $1(n=201)$ & 0,5 & $0(n=130)$ & 0 & 1,00 \\
\hline Mucor mucedo & $0(n=201)$ & 0 & $0(n=130)$ & 0 & - \\
\hline Candida albicans & $0(n=201)$ & 0 & $0(n=130)$ & 0 & - \\
\hline Akar genel* duyarlılığı & $126(n=201)$ & 62,7 & $102(n=130)$ & 78,4 & 0,002 \\
\hline Dermatophagoides farinae & $116(n=201)$ & 57,7 & $98(n=130)$ & 75,3 & 0,001 \\
\hline Dermatophagoides pteronyssinus & $124(n=201)$ & 61,7 & $100(n=130)$ & 76,9 & 0,003 \\
\hline Çimen polen genel* duyarlılığı & $107(n=201)$ & 53,2 & $55(n=130)$ & 42,3 & 0,047 \\
\hline Cynodon dactylon & $81(n=170)$ & 47,6 & $38(n=108)$ & 35,2 & 0,041 \\
\hline Lolium perenne & $57(n=112)$ & 50,9 & $29(n=77)$ & 37,7 & 0,073 \\
\hline Phleum pratense & $95(n=179)$ & 53,1 & $44(n=113)$ & 38,9 & 0,018 \\
\hline Tahıl polen genel* duyarlılığı & $104(n=201)$ & 51,7 & $49(n=130)$ & 37,7 & 0,012 \\
\hline Avena sativa & $82(n=168)$ & 48,8 & $41(n=109)$ & 37,6 & 0,67 \\
\hline Secale cereale & $96(n=181)$ & 53,0 & $45(n=116)$ & 38,8 & 0,016 \\
\hline Ağaç polen genel* duyarlılığı & $51(n=201)$ & 25,3 & $27(n=130)$ & 20,7 & 0,395 \\
\hline Alnus glutinosa & $14(n=182)$ & 7,7 & $11(n=115)$ & 9,6 & 0,725 \\
\hline Corylus avellena & $13(n=166)$ & 7,8 & $6(n=103)$ & 5,8 & 0,704 \\
\hline Olea europeae & $35(n=197)$ & 17,8 & $20(n=127)$ & 15,7 & 0,748 \\
\hline Yabani ot polen genel* duyarlılığı & $36(n=201)$ & 17,9 & $17(n=130)$ & 13,0 & 0,361 \\
\hline Artemisia vulgaris & $12(n=142)$ & 8,5 & $9(n=90)$ & 10,0 & 0,868 \\
\hline Plantago lanceolata & $3(n=71)$ & 4,2 & $2(n=38)$ & 5,3 & 1,00 \\
\hline Pariteria judaica & $9(n=81)$ & 11,1 & $5(n=61)$ & 8,2 & 0,77 \\
\hline \multicolumn{6}{|l|}{ Diğer } \\
\hline Kedi & $16(n=178)$ & 9,0 & $12(n=118)$ & 10,2 & 0,891 \\
\hline Köpek & $7(n=183)$ & 3,8 & $7(n=116)$ & 6,0 & 0,548 \\
\hline Hamam böceği & $3(n=197)$ & 1,5 & $8(n=127)$ & 6,3 & 0,027 \\
\hline
\end{tabular}

*genel duyarlıık: o gruptaki alerjenlerden en az birine karşı pozitif deri prik testi sonucu varlığı 
rinitli hastalarda ek olarak astım görülme riskini Dermatophagoides farinae duyarlıığının 2,5 kat (OR: 2,54; 95\%Cl: 1,4-4,4; $p=0,001)$, hamam böceği duyarlılığı varlığının ise 3,9 kat (OR: $3,9 ; 95 \% \mathrm{Cl}: 0,9-15,3 ; p=0,05)$ anlamlı risk faktörleri olarak artırdığı belirlendi.

\section{TARTIŞMA VE SONUÇ}

Çocukluk çağında alerjik rinit erkeklerde daha sık görülmekle birlikte erişkin yaş grubunda her iki cinsiyet eşit olarak etkilenmektedir (9). Alerjik rinit semptomları olguların \%80'inde 20 yaşından önce başladığı, hastaların \%20'sinde iki-üç yaşlarda, \%40'ında ilk altı yaşta, yaklaşık \%30'unda da adölesan dönemde ortaya çıktı̆ı bildirilmektedir (10). Çalışmamızda yer alan olguların cinsiyet dağılımı, ortalama tanı yaşları ve semptomların başlangıç zamanları daha önceki literatür verileri ile benzerlik taşımaktadır (11-20).

Alerjik rinit ve astım birlikteliği; burun ve bronş mukoza yapısının benzer olması, rinit ve astım patogenezinde alerjenlerin rolü ve rinitin astım patogenezindeki katkısı nedenleriyle sık olarak görülmektedir (9). Çalışmamızda da alerjik rinite eşlik eden en sık hastalık astım olarak $(\% 39,3)$ saptanmıştır.

Türkiye'de çocuklarda farklı bölgelerde mantar alerjenleri duyarlıı̆̆ı sonuçlarını içeren çeşitli çalışmalarda farklı oranlar bildirilmektedir. Elmas ve ark.'nın (21) Sakarya ilinde alerjik rinitli çocuklarda inhalan alerjenlere duyarlılık oranlarının araştırdığı çalışmada, mantar alerjenleri duyarlılığı \%7,6, Alternaria duyarlılığı \%5,2, Cladosporium duyarlılığı \%2,4 olarak saptanmıştır. Ülkemizde Trakya bölgesinde yapılan bir çalışmada 4-17 yaş arası alerjik rinit ve astım tanısı alan çocuklarda deri prik testi ile mantar alerjenleri duyarlılığı \%32,3 oranında saptanmıştır (22). Ankara'da okul öncesi solunumsal sorunları olan çocuklarda yapılan çalışmada, 177 atopik çocukta \%7,9 oranında Alternaria'ya karşı deri prick testi ile duyarlılık saptanmıştır, 152 alerjik rinitli olgunun \%0,65'inde Alternaria duyarlılığı saptanmıştır (23). Ülkemizde Bavbek S ve ark.'nın yaptığı diğer bir çalışmada çocuk ve erişkin astım ve rinitli olgularda Alternaria duyarlılığı $\% 11,9$, Cladosporium duyarlılığı \%8,1 oranında saptanmıştır. (24). Türkiye dışında yapılan çalışmalarda, Moral L ve ark.'nın (25) İspanya'da 15 yaş alt 2181 astım ve alerjik rinitli olguda yaptığı çalışmada ise Alternaria duyarlılığı oldukça yüksek bir oran olarak \%33 olguda, monosensitize Alternaria duyarlılığı ise \%17 olguda saptanmıştr. Tayland'da 2-15 yaş arasında değişen 98 alerjik rinitli çocuk ile yapılan çalışmada 63 sadece rinitli olguda deri prik testi ile Alternaria duyarlılığı \%10, Penicilium $\% 13$, Aspergillus \%5, Cladosporium \%2 oranında saptanırken; alerjik rinit ve astımlı 35 olguda Alternaria duyarlılığı \%11,4, Penicilium \%2,8, Aspergillus \%17,1, Cladosporium \%20 oranında saptanmıştır (26). Singapur'da 2001-2002 yıllarında yapılan bir çalışmada yaşları 2-14 arasında değişen 202 alerjik rinitli olguda deri prik testi ile mantar duyarlılığı \%19 olarak saptanmıştır (27). Singapur'da 2003-2004 yıllarında yapılan diğer bir çalışmada ise 2-16 yaşları arasındaki 175 alerjik rinitli olguda mantar alerjenleri duyarlıı̆̆ı \%9 olarak saptanmıştır (28).

Güney Marmara bölgesi ve Bursa ilinden alerjik rinitli olguların değerlendirmeye alındığı sunulan bu çalışmamızda ise, deri prik testleri ile en az bir mantar alerjenine duyarlılık \%10,6 oranında, Alternaria alternata duyarlılığı \%9,4 olguda, monosensitize Alternaria alternata duyarlılığı \%2,1 olguda saptandı. Mantar alerjenlerine duyarlılık saptanan olgular içinde, mantar alerjen duyarlılıklarının büyük çoğunluğunu Alternaria alternata $(\% 88,5)$ duyarlıığı oluşturmaktaydı. Çeşitli mantar alerjen duyarlılıkları görülme oranlarında, iklim ve coğrafi şartlara göre ev içi veya ev dışı ortamlarda bulunan mantar alerjenlerinin yoğunluklarının değişkenlikler göstermesine bağlı olarak, ülkelere ve bölgelere göre değişik sonuçlar saptanabileceği bilinmektedir. Türkiye'de en sık görülen alerjenler bölgelere göre değişmektedir, ılıman iklimin hâkim olduğu bölgelerde akar alerjenleri ilk sırada görülürken, karasal iklimin görüldüğü bölgelerde en sık görülen alerjenler olarak polenler tespit edilmiştir $(12,16,25,29,30)$. Bu çalışmada alerjik rinitli olgularda saptanan mantar dışı diğer alerjenlere karşı duyarlılık oranları ülkemizden bildirilen diğer çalışma sonuçları ile genel olarak benzer oran ve sıralamada olduğu görülmektedir.

Mantar alerjenleri duyarlılığı alerjik rinit semptomlarının ortaya çıkışını ve semptom süresini etkilemektedir. Codispoti ve ark. tarafindan yapılan bir çalışmada erken dönemde oluşan mantar alerjen duyarlıığının alerjik rinit için önemli bir predispozan faktör olduğu saptanmıştır (31). Çalışmamızda da mantar alerjen duyarlılığı olan grupta rinit semptomlarının ortalama başlangıç yaşı, duyarlılığı olmayanlara göre anlamlı olarak daha düşük saptanmışttr. Bavbek S ve ark.'nın astım ve alerjik rinitli çocuk ve erişkin hastalarda yaptığı çalışmada ise mantar alerjen duyarlılığı olan grupta, mantar alerjen duyarlılığı olmayan gruba göre semptomların süresinin (gün) istatistiksel olarak daha uzun olduğu görülmüştür (24). Mantar duyarlılığı saptanan ve saptanmayan gruplar arasında total IgE düzeyleri ve total eozinofil sayıları açısından anlamlı farklıııklar saptanmadı. Bu veriler mevcut literatür bilgileri ile uyumlu değerlendirilmiştir, mantar duyarlılığı saptanan alerjik rinitli olgular ile mantar alerjenlerine duyarlılık saptanmayan alerjik rinitli olgular arasında total IgE düzeyleri ve total eozinofil sayıları açısından farklılıklar bildirilmemektedir $(2,3)$.

Mantar alerjen duyarlıı̆̆ı olan grupta, olmayanlara göre akar duyarlıı̆̆ı anlamlı olarak düşük, Alnus glutinosa, Corylus avellena, yabani ot polen genel, Artemisia vulgaris ve köpek alerjen duyarlılıkları ise anlamlı olarak yüksek saptanmıştır. Konuyla ilgili olarak alerjik astım ve rinit tanılı olgularla yapılan bir çaışmada mantar alerjenleri duyarlıı̆̆ı ile akar duyarlılığı arasında herhangi bir ilişki saptanmamıştır (24). Literatür verilerinde alerjik rinitli hastalarda mantar alerjen duyarlılığı ile ev tozu akarları duyarlılığı arasında negatif bir ilişki varlığı ile ilgili başka bir veriye rastlanmamıştır, bu çalışmada elde edilen bu verinin çalışma popülasyonunun görece çok fazla sayıda hastadan oluşmaması veya bu çalışmada incelenmemiş olan başka etkenlerle ilgili olabileceği de düşünülmüştür. Çalışmamızda alerjik rinitli olgularda mantar alerjenlerine duyarlılık varlığı için, Corylus avellena veya köpek alerjen duyarlılığı varlığının anlamlı risk faktörleri olduğu saptandı, yine bu konuyla ilgili de literatürde herhangi bir veriye rastlanılmamıştır. Bu çalışmada elde edilen bu konudaki verinin çalışma popülasyonunun içerdiği hasta sayısı ile veya bu çalışmada çalışı mayan başka farklı değişkenlerle 
de ilgili olabileceği düşünülmüştür. Bu konularla ilgili kesin bir kanıya varabilmek için daha geniş populasyonlarda ileri araştırmalara ihtiyaç vardır.

Mantar alerjenlerinin astımda önemli bir yere sahip olduğu bilinmektedir ve mantar alerjenlerine duyarlılık çalışmaları daha çok astımlı hasta grupları üzerinde gerçekleştirilmiştir. Türkiye'de ve farklı diğer ülkelerde yapılan çeşitli çalışmalarda astım ve alerjik rinit birlikteliği ile mantar alerjen duyarlılığı arasında istatistiksel bir ilişki bildirilmemiştir $(26,29,30)$. ÇaIışmamızda; alerjik rinitli olgularda tabloya astımın eşlik edip etmemesine göre değerlendirildiğinde alerjik rinit ile astım tablosu birlikte olan grupta akar genel, Dermatophagoides pteronyssinus, Dermatophagoides farinae ve hamam böceği duyarlılıkları istatistiksel anlamlı olarak yüksek oranlarda saptanırken, mantar sporu genel, Alternaria alternata, Aspergillus fumigatus ve diğer mantar alerjenleri duyarlılıkları için iki grup arasında istatistiksel anlamlı bir farklılık saptanmadı. Akar alerjenlerinin astımlı bireylerde en sık rastlanan alerjen olduğu bilinmektedir $(29,30)$. Akarlar astım gelişimi ve astımlı olgularda semptomların ortaya çıkışını tetikleyen en önemli ve en sık rastlanan alerjenlerdir. Ancak astımlı olgularda akar duyarlılığı oranları çevresel özelliklere, iklime, coğrafik özelliklere, toplumlara göre değişik oranlarda saptanmaktadır. Çeşitli çalışmalarda; sadece alerjik rinitli olgularda, astım ile birlikte olan alerjik rinitli olgulara göre polen duyarlılıklarının daha yüksek olduğu gösterilmiştir $(12,29,30)$. Çalışmamızda da benzer şekilde tek başına alerjik rinitli olgularda; çimen polen genel, Cynodon dactylon, Phleum pratense, tahıl polen genel, Secale cereale duyarlılıkları istatistiksel olarak anlamlı olarak daha yüksek saptanmıştır.

Sonuç olarak bölgemizde alerjik rinitli çocuk olgularda mantar alerjen duyarlılıkları önemli bir oranda görülmektedir. En sık duyarlııı görülen mantar alerjeni Alternaria alternata'dır. Mantar alerjenlerine duyarlılığı olan olgularda yakınmalar daha erken yaşlarda ortaya çıkmaktadır. Mantar duyarlılığı saptanan ve saptanmayan gruplar arasında total IgE düzeyleri ve total eozinofil sayıları açısından anlamlı farklııklar saptanmamıştır. Alerjik rinitli olgularda, birlikte astım görülme için Dermatophagoides farinae ve hamam böceği duyarlılığı varlığının anlamlı risk faktörleri olduğu belirlenmiştir. Mantar alerjenlerine duyarıılığı olan olgularda akar alerjen duyarlılığı sıklığı daha az oranda görülmekte ve mantar alerjenlerine duyarlılık için, Corylus avellena duyarlılığının veya köpek alerjen duyarlılığı varlığının anlamlı risk faktörleri olduğu gözlenmekle birlikte, bu verilerin çalışma popülasyonunun boyutuna veya diğer başka etkenlere de bağlı olabileceği de düşünülmüştür. Bu veriler ile ilgili daha geniş populasyonlarda ileri araştırmalara ihtiyaç vardır.

Etik Komite Onayı: Araştırma için Uludağ Üniversitesi Tıp Fakültesi Bilimsel Araştırmalar Etik Kurulu'ndan (2009.11/72 tarih ve sayılı kararı) onay alınmıştır.

Bilgilendirilmiş Onam: Katlımcılardan bilgilendirilmiş onam alınmıştır.

Hakem Değerlendirmesi: Dış bağımsız.

Yazar Katkıları: Çalışma Konsepti/Tasarım- M.B., Y.C., Ş.Ç., G.O., N.S.;
Veri Toplama- M.B., Ş.Ç.; Veri Analizi/Yorumlama- Y.C., G.O., N.S.; Yazı Taslağı- M.B., Y.C., Ş.Ç., G.O., N.S.; İçeriğin Eleştirel Incelemesi- Y.C., N.S.; Son Onay ve Sorumluluk- M.B., Y.C., Ş.C.., G.O., N.S

Çıkar Çatışması: Yazarlar çıkar çatışması beyan etmemişlerdir.

Finansal Destek: Yazarlar finansal destek beyan etmemişlerdir.

Ethics Committee Approval: This study was approved by the Uludağ University Faculty of Medicine Scientific Research Ethics Committee (2009.11/72).

Informed Consent: Written consent was obtained from the participants.

Peer Review: Externally peer-reviewed.

Author Contributions: Conception/Design of Study- M.B., Y.C., Ş.Ç., G.O., N.S.; Data Acquisition- M.B., Ş.Ç.; Data Analysis/InterpretationY.C., G.O., N.S.; Drafting Manuscript- M.B., Y.C., Ş.Ç., G.O., N.S.; Critical Revision of Manuscript- Y.C., N.S.; Final Approval and AccountabilityM.B., Y.C., Ş.Ç., G.O., N.S

Conflict of Interest: Authors declared no conflict of interest.

Financial Disclosure: Authors declared no financial support.

\section{KAYNAKLAR/REFERENCES}

1. Wallace DV, Dykewicz MS, Bernstein DI, Blessing-Moore J, Cox L, Khan DA, et al. The diagnosis and management of rhinitis: an updated practice parameter. J Allergy Clin Immunol 2008;122(2 suppl):1-84.

2. Dykewicz MS, Wallace DV, Amrol DJ, Baroody FM, Bernstein JA, Craig TJ, et al. Rhinitis 2020: A practice parameter update. J Allergy Clin Immunol 2020;146(4):721-767.

3. Meng $\mathrm{Y}$, Wang $\mathrm{C}$, Zhang L. Recent developments and highlights in allergic rhinitis. Allergy 2019;74:2320-8.

4. Corsico R, Cinti B, Feliziani V, Gallesio MT, Liccardi G, Loreti A, et al. Prevalance of sensitization to alternaria in allergic patients in Italy. Ann Allergy Asthma Immunol 1998;80:71-6.

5. Hocaoğlu AB, Karaman Ö. Çocukluk Çağında Allerjik Rinit- Derleme. Güncel Pediatri 2010;8:105-12.

6. Dickerson PJK, Li J. Effects of damp and mould in the home on respiratory health: a review of the literature. Allergy 1998;53:1208.

7. Heinzerling L, Frew AJ, Bindslev-Jensen C, Bonini S, Bousquet J, Bresciani $\mathrm{M}$, et al. Standard skin ptik testing and sensitization to inhalant allergens across Europe-a survey from the GA(2)LEN network. Allergy 2005;60:1287-300.

8. Position paper: Allergen standardisation and skin tests. The European Academy of Allergology and Clinical Immunology. Allergy 1993;48:48-82.

9. Gentile DA, Shapiro GG, Skoner DP. Allergic Rhinitis. Leung DYM, Sampson HA, Geha RS, Szefler, SJ editors. Pediatric Allergy: Principles and practice. Mosby-Year Book, Inc, St. Louis, MO. 2003:287-97.

10. Wright AL, Holberg CJ, Martinez FD, Halonen M, Morgan W, Taussig LM. Epidemiology of physician-diagnosed allergic rhinitis in childhood. Pediatrics 1994;94:895-901. 
11. Harmancı K, Bakıtaş A, Türktaş İ. Sensitization to Aeroallergens in Preschool Children with Respiratory Problems in Ankara, Turkey. Turkish Respiratory Journal 2006;7(1):10-4.

12. Yazicioglu M, Oner N, Cetlik C, Okutan O, Pala O. Sensitization to common allergens, especially pollens, among children with respiratory allergy in the Trakya region of Turkey. Asian Pac J Allergy Immunol 2004;22:183-90.

13. Balatsouras DG, Koukoutsis G, Ganelis P, Fassolis A, Korres GS, Kaberos A. Study of Allergic Rhinitis in Childhood. Int J Otolaryngol 2011. doi:10.1155/2011/487532.

14. Meltzer EO, Blaiss MS, Derebery MJ, Mahr TA, Gordon BR, Sheth KK, et al. Burden of allergic rhinitis: results from the Pediatric Allergies in America survey. J Allergy Clin Immunol 2009;124(suppl):S43-70.

15. Lee JT, Lam ZCM, Lee WT, Kuo LC, Jayant V, Singh G, et al. Familial Risk of Allerjic Rhinitis and Atopic Dermatitis among Chinese Families in Singapore. Ann Acad Med Singapore 2004;33:71-4.

16. Kidon MI, See $\mathrm{Y}$, Goh A, Chay OM, Balakrishnan A. Aeroallergen sensitization in pediatric allergic rhinitis in Singapore: Is airconditioning a factor in the tropics? Pediatr Allergy Immunol 2004;15:340-3.

17. Kidon MI, Chiang WC, Liew WK, Lim SH, See Y, Goh A, et al. Sensitization to dust mites in children with allergic rhinitis in Singapore: does it matter if you scratch while you sneeze? Clin Exp Allergy 2005;35:434-40.

18. Bostancı I, Turktas I, Turkyılmaz C. Sensitization to aeroallergens in Ankara, Turkey. Allergy 1999;54:1328-36.

19. Dold S, Wjst M, von Mutius E, Reitmeir P, Stiepel E. Genetic risk for asthma, alllergic rhinitis, and atopic dermatitis. Arch Dis Child 1992;67:1018-22.

20. Sobki SH, Zakzouk SM. Point prevalence of allergic rhinitis among Saudi children. Rhinology 2004;42:137-40.

21. Elmas B, Özdemir Ö. Sensitization Prevalence of Children with Allergic Rhinitis for Inhalant and Food Allergens in the Province of Sakarya, Turkey. JAREM 2017;7:63-9.
22. Yazicioglu M, Oner N, Cetlik C, Okutan O, Pala O. Sensitization to common allergens, especially pollens, among children with respiratory allergy in the Trakya region of Turkey. Asian Pac J Allergy Immunol 2004;22:183-90.

23. Harmancı K, Bakıtaş A, Türktaş I. Sensitization to Aeroallergens in Preschool Children with Respiratory Problems in Ankara, Turkey. Turkish Respiratory Journal 2006;7(1):10-4.

24. Bavbek S, Erkekol FO, Ceter T, Mungan D, Ozer F, Pinar M, et al. Sensitization to Alternaria and Cladosporium in patients with respiratory allergy and outdoor counts of mold spores in Ankara atmosphere, Turkey. J Asthma 2006;43(6):421-6.

25. Moral L, Roig M, Gadre J, Alós A, Toral T, Fuentes MJ. Allergen sensitization in children with asthma and rhinitis: marked variations related to age and microgeographical factors. Allergol Immunopathol (Madr) 2008;36:128-33.

26. Sritipsukho P. Aeroallergen Sensitivity Among Thai Children with Allergic Respiratory Disease:A Hospital-Based Study. Asian Pac J Allergy and Immunol 2004;22:91-5.

27. Kidon MI, See Y, Goh A, Chay OM, Balakrishnan A. Aeroallergen sensitization in pediatric allergic rhinitis in Singapore: Is airconditioning a factor in the tropics? Pediatr Allergy Immunol 2004;15:340-3.

28. Kidon MI, Chiang WC, Liew WK, Lim SH, See Y, Goh A, et al. Sensitization to dust mites in children with allergic rhinitis in Singapore: does it matter if you scratch while you sneeze? Clin Exp Allergy 2005;35:434-40.

29. Yilmaz A, Tuncer A, Sekerel BE, Adalioglu G. Cockroach allergy in a group of Turkish children with respiratory allergies. Turk J Pediatr 2004;46:344-9.

30. Küçükosmanoğlu E, Keskin Ö. Gaziantep'te Çocuklarda Solunum Allerjenleri Duyarlııı̆ı. Astım Allerji İmmünoloji 2008;6:141-5.

31. Codispoti CD, Bernstein DI, Levin L, Reponen T, Ryan PH, Biagini Myers JM, et al. Early-life mold and tree sensitivity is associated with allergic eosinophilicrhinitis at 4 years of age. Ann Allergy Asthma Immunol 2015;114(3):193-8. 